\title{
Probiotics and medicinal plants in poultry nutrition: a review
}

\author{
${ }^{1}$ Akintayo - Balogun Omolere. M and ${ }^{2}$ Alagbe, J.O \\ ${ }^{1}$ University of Abuja, Nigeria \\ ${ }^{2}$ Sumitra Research Institute, Gujarat, India \\ Leretayo98@gmail.com
}

\begin{abstract}
The use of medicinal plants and probiotics has recently gained interest since the ban on the use of antibiotics as growth promoters by the European Union in 2006. They are new alternatives to bridge the gap between food safety and production. Medicinal plants are cheaper and loaded with several minerals, vitamins and phytochemicals such as: alkaloids, saponin, flavonoids, phenols, tannins etc. which allows them to perform multiple biological activities. Probiotics on the other hand, repopulates the gastro intestinal tracts (GIT) with beneficial bacteria which controls the action of pathogens and control their population, thereby reducing mortality and improving general performance of an animal.
\end{abstract}

Keywords: Probiotics; medicinal plants; pathogens; phytochemicals.

\subsection{INTRODUCTION}

Poultry production has experienced a remarkable growth within the past four decades in its bid to attain viable level of production but there are still a lot of problems confronting the industry such as disease, high cost of feed cost and most recently the indiscriminate use of antibiotics. The sub-therapeutic use of antibiotics in poultry production is a public health concern because of antimicrobial resistance and the presence of their residues in final products leading to several health challenges in humans. These situations prompted the European Union in 2006 to place a ban on the use of the use antibiotic feed additives to promote food safety. Among the potential alternative to antibiotics is the use of medicinal plants (phytobiotics/phytogenics) and probiotics which contains one or more useful bacteria or yeast (Waldroupet al., 2003; Navaet al., 2005) which promotes healthy gut and prevents disbiosis which could occur during stress, prolong water deprivation, feed fasting and infections (caused by viruses, bacteria, fungi and protozoa), causing an imbalance of flora with a proliferation of undesirable microorganisms (Filipe (2014).

According to Sommer and Backhed (2013), the gastro intestinal tract (GIT) is an important site of digestion, nutrient absorption, intestinal integrity, nutrient metabolism and fermentation. McDevitt et al. (2006); Neeraj (2016) opined that exposure of GIT to harmful infectious agents or pathogens (Escherichia coli, Clostridium, Pseudomonas, Blastomyces and Salmonella) could cause an imbalance in intestinal flora, productivity loss and immune suppression.

Probiotics are live cultures of organisms supplemented in poultry diets that can beneficially affect the host animal by improving the microbial balance in the gut (Kroimayr and Zhang, 2006). They have shown positive results towards improving performance in birds (Vicentet al., 2007), feed efficiency (Hassan et al., 2014; Samliet al., 2007), change in gastrointestinal microflora (Mountzouriset al., 2007; Kudohet al., 1998), nutrient absorption (Amatet al., 1996; Alagbe, 2019), reduction in pathogenic microorganisms (Leandro et al., 2010; Liu et al., 2008), immune booster (Kim et al., 2009; Knap et al., 2011). Organisms used as probiotics must fulfill the above criteria before been considered and must be generally regarded as safe [GRAS] as presented in Fig 1. The most commonly used include Lactobacillus acidophilus, Enterococci faecium andBacillus spp. (Schone, 2006).

According to Filipe (2014), probiotics administration repopulates the GIT with beneficial with beneficial bacteria which curbs the action of pathogens and controls their population. This is especially after stressful events such as drastic changes in the diet, fasting, erratic temperatures or after exposure to aggressors such as enteritis of bacteria or viral origin in the microbiota and mycotoxin contamination in feed.

\subsection{MECHANISM OF ACTION OF PROBIOTICS}

The mode of action of probiotics is not always well understood due to different strains that may have various functions and survivability throughout the gut affecting the host in different ways. The effects of probiotics can be classified in: 
1) Interaction between probiotic-microbe-gut epithelium: Adhesion to mucosal epithelial cells, stimulation of mucus secretion, prevention of adhesion of pathogens as probiotics blocking intestinal receptors, thereby excluding pathogens, enterotoxins and hampering proliferation of pathogens, competition with pathogens for important nutrients, secretion of antimicrobial and antitioxin substances that affects establishment and or replication of pathogens in the gastrointestinal tract (Collado, 2009)

2) Interaction between probiotic-immune system: Immunemodulation by innate as well as systemic ways, enhancing and reinforcing gut integrity and gut barrier function, eventually decreasing secretory and inflammatory molecules against microbial infection (Servin, 2004). The general mechanisms by which probiotics may have an effect can be divided into various categories: adhesion activity to gut mucosal epithelium, antitoxic effect, modulation of immune system, production of antimicrobial substances and competitive exclusion between probiotics and pathogenic bacteria.

\subsection{RELEVANCE OF A BALANCED GUT}

According to Klasing (1987), there is a correlation between gut microbiota imbalance and poor growth performance. In other words, pathogenic organisms compete with animals for nutrients which could lead to poor performance and eventually death depending on its severity. Kristy (2015) opined that the acquisition of a positive microbiota in the first few days after hatching has a profound effect on the overall health of the bird. Similar observation was made by Filipe (2014) who reported that newly hatched industrial chicks do not come into contact with mother hens and are placed in a clean, sanitized environment with little opportunity for rapid development of a protective intestinal microflora that can successfully compete with pathogens. The first days of life are a critical period of time with high risk of infection by pathogens such as E.coli, Salmonella etc. that may be present in the litter. Thus, probiotic supplementation is beneficial measure as expressed in Fig 2.

\subsection{PROBIOTICS FOR POULTRY}

In modern broiler production many factors can enhance stressors, they include feed changes or imbalances, transportation, processing at the hatchery and high stocking densities. During post hatching period, which ultimately affects the colonization of the gastrointestinal tract by bacterial pathogens due to weakened immune system, posing a threat to bird and food safety.

In a comprehensive research in turkeys and chickens, commercial researches have established that proper administration of probiotics mixture increased performance, reduced costs of production as well as was effective in reducing abdominal fat deposition (Vincente et al, 2007). Timmerman et al. (2006) reported that the main factors affecting the efficacy of the probiotic preparations depend on way and timing of the administration. Application through the feed than application in the drinking water resulted in a higher increase of average daily gain.

Eggs production has been also investigated in relation to probiotic application. A combined mix culture of Lactobacillus acidophilus, L. casei, Bifidobacteriumthermophilus and Enterococcus faecium enhanced egg size and lowered feed cost in laying hens (Davis and Anderson, 2002). Moreover, Bifidobacteriumthermophilus and Enterococcus faecium improved egg production and quality (Kutoglu et al, 2004). The use of Enterococci as probiotics in chickens prolonged feeding with E. faecium based probiotics increased egg laying intensity and feed conversion efficiency (Koudela et al, 1996). In poultry, benefits of yeast probiotic supplementation are established in broilers' production performance and increased resistance of chickens to enteric pathogens infections (Salmonella, Campylobacter jejuni, E. coli or C. perfringens) (Banjeree and Pradhan, 2006). Furthermore, supplementation with yeast treatment significantly decreased the frequency of Salmonella colonization to lower than the pre-stress (before transport) levels, whereas non-supplemented birds had higher levels of Salmonella colonization (Line et al., 1997).

\subsection{MEDICINAL PLANTS}

The use of plants in traditional medicine has been in existence for thousands of years because plants have proven to be a natural renewable resource with valuable bioactive compounds (Cherkupallyet al., 2017; Lina, 2017; Oluwafemi et al., 2020) and also provided a clue on the discovery of new products of medicinal value for drug development (Senthilkumaret al., 2018). According to Rates (2001) out of the about 250,000 - 500,000 plant species estimated by the WHO (1992), only a small percentage has been investigated phytochemically and even a smaller percentage has been properly studied in terms of their pharmacological properties. 
The primary benefits of using plants or herbs (essential oil, spices, extracts) is that they are relatively safer than synthetic alternatives offering profound therapeutic benefits and more affordable (cheaper) in the treatment of diseases (Manjuet al., 2011). The presence of phytochemicals or bioactive (flavonoids, alkaloids, saponins, phenol, oxalate etc.) confers plant the ability to perform multiple biological functions as anti-inflammatory (Sathyaet al., 2012; Omokore and Alagbe, 2019; Khan et al., 2009), antioxidants (Wang et al., 2008; Alagbe et al., 2019), antifungal (Parkash et al., 2002), expectorant (Partap et al., 2012; Arczewska and Swiatkiewicz, 2012), antimicrobial (Olafadehan et al., 2020; Wojdylo et al., 2007), anti-parasitic (Ighodaro et al., 2012; Zinoviadou et al., 2009), antiviral (Olafadehan et al., 2020; Srinivasan, 2005), antihyperglycemic (Tassou et al., 2000) and antidiabetics (Viegi et al., 2003).

Phytochemicals can be used in solid, dried and ground form or as extracts (crude or concentrated), and also can be classified as essential oils (essential oils, volatile lipophilic substances obtained by cold extraction or steam/alcohol distillation) and oleoresins (extracts derived by non-aqueous solvents) depending on the process used to derive the active ingredients (Gadde et al., 2017). The secondary metabolites in plants varies in composition and concentration, method of extraction (aqueous, ethanolic and methanolic), stage of growth, storage conditions, geographical location (Alagbe, 2019; Hyun et al., 2018).

\subsection{ROLE OF MEDICINAL PLANTS IN MONOGASTRIC 1.5.1 Maintaining the integrity of the gastro intestinal tract (GIT)}

According to Bravo and Ionescu (2008) mixture of a mixture of carvacrol, cinnamaldehyde and capsicum oleoresin in broilers stabilizes the intestinal microbiota and reduces microbial toxic metabolites in the gut, owing their direct antimicrobial properties on various pathogenic bacteria which result in relief from intestinal challenge and immune stress.

Hanan (2015) evaluated the effect of supplementing different levels of turmeric on the turmeric on the caecal microbial population of broiler chicks he observed that birds fed diet supplemented at $0.4 \%$ significantly (P<0.05) reduced Escherichia coli count in the caecum. However, Lactobacilli count, weight gain were significantly $(\mathrm{P}<0.05)$ highest for all treatment supplemented with turmeric powder.

Phyoet al. (2017) also observed the effect of dietary garlic and thyme seed supplementation on the production performance and gut microbial population of broiler chickens. Treatments were control diet (T1), control diet with $1 \%$ thyme seed powder (T2), control diet with $1 \%$ garlic powder (T3) and control diet with $0.5 \%$ thyme seed and $0.5 \%$ garlic powder (T4). E.coli count in the gut of the birds did not show dietary treatments compared to control. However, Lactobacilli in the gut of broilers significantly $(P<0.05)$ increased in T2, T3 and T4 compared to that of T1. It was concluded that thyme and garlic could provide positive advantages to the colonization and proliferation of Lactobacilli. 
FIGURE 1: PROBIOTICS SELECTION CRITERIA

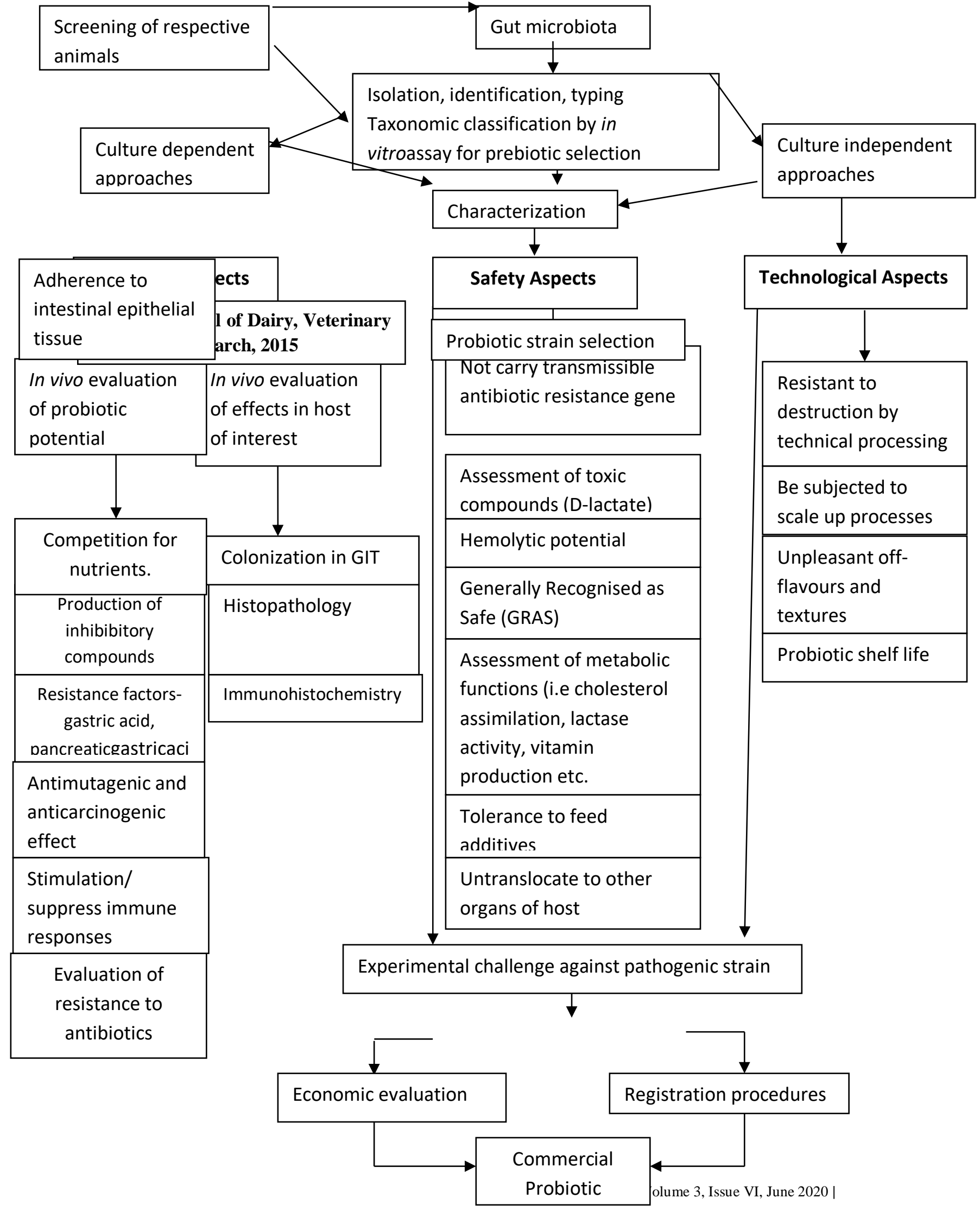


Alagbeet al. (2019) conducted to evaluate the carcass, caeca microbial parameters of broilers fed different levels of mixed lemon grass and garlic extract (CLGE). Five hundred broiler chickens (Ross 308) were allotted to five treatments with five replicate consisting of 20 birds each in a completely randomized design (CRD). The first group T1 was given $0.025 \mathrm{~g} /$ litre Neomycin in water while T2, T3, T4 and T5 were given CLGE at levels 3.0ml/litre, $6.0 \mathrm{ml} /$ litre, $9.0 \mathrm{ml} /$ litre and $12.0 \mathrm{ml} /$ litre of water respectively. The experiment lasted for four weeks each for the starter and finisher respectively. Results on dressing percentages revealed that birds given $12.0 \mathrm{ml} / \mathrm{l} \mathrm{CLGE} \mathrm{was} \mathrm{highest}$ (76.87\%) followed by those in T4 (76.54\%), T3 (75.61\%), T2 $(75.00 \%)$ and T1 $(70.01 \%)$. Significant influences $(\mathrm{P}<0.05)$ were also observed in the relative organ weight (liver, kidney, spleen, heart, pancreas, gizzard and proventriculus). There were also significant differences $(\mathrm{P}<0.05)$ in the caeca microbial population of E.coli and lactobacillus count as well as the antibody titer against Newcastle and gumboro disease. Birds in T5 had the lowest E.coli count $(9.00 \mathrm{cfu} / \mathrm{g})$ when compared to $\mathrm{T} 1(22.19 \mathrm{cfu} / \mathrm{g})$ with the highest proportion of the bacteria. It was concluded that CLGE could be given to broilers at $12.0 \mathrm{ml} /$ liter without any negative effect on the health and can be used to effectively replace antibiotics.

Figure 2. Schematic representation of the concept of probiotics

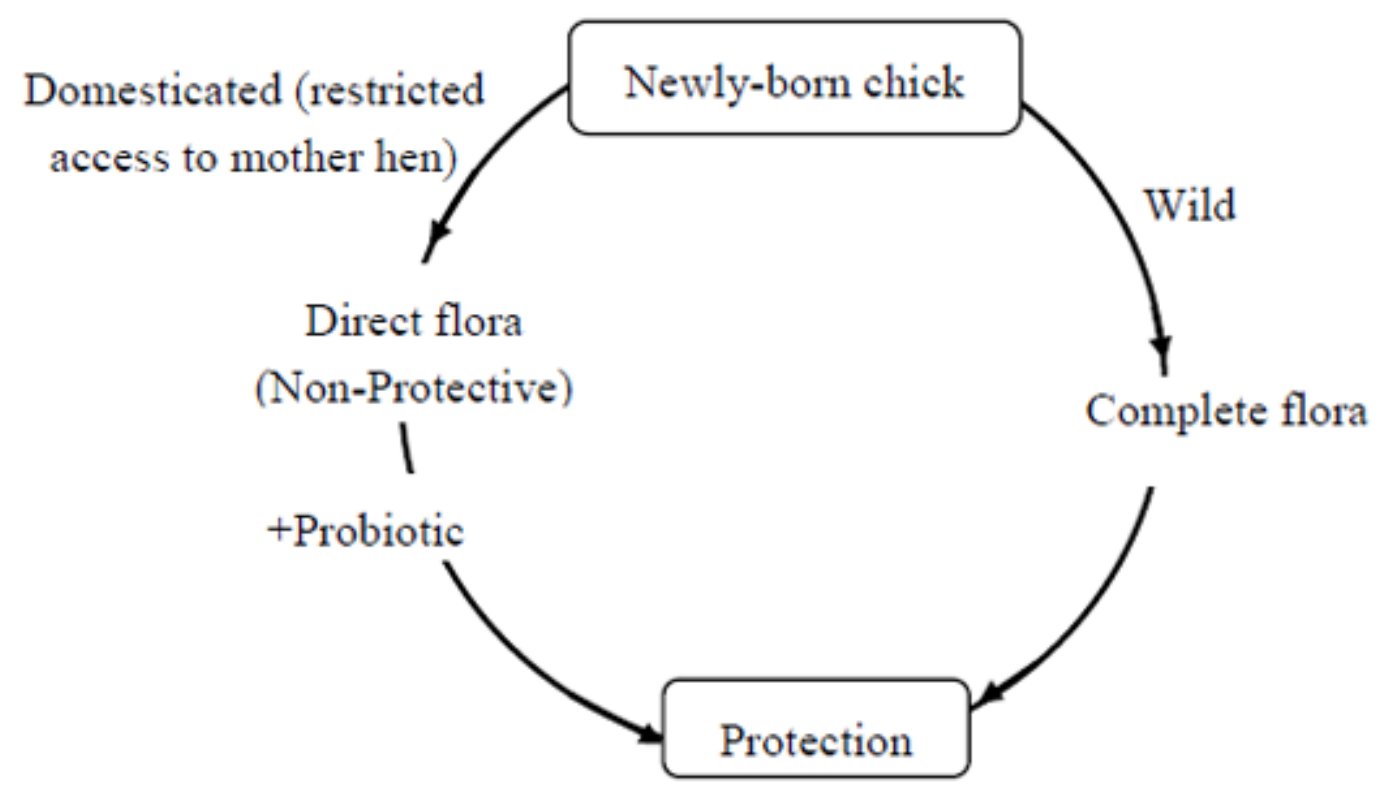

*Source: Fuller (2001); LutfulKabir (2009)

\section{CONCLUSION}

Phytogenics and probiotics have the ability to stabilize the intestinal environment and provide positive advantages to the colonization and proliferation of Lactobacilli and reducing pathogenic organisms. Also theuse of medicinal plants is safer and cheaper. It could also serve as a way of bridging the gap between food safety and production as well as reducing mortality in animals.

\section{REFERENCES}


1. Arczewska,W.AamdSwiatkiewicz, S. (2012). The effect of a dietary herbal extract blend on the performance of broilers challenged with Eimeriaoocysts. Journal of Animal and Feed Science, 21:133-142.

2. Fuller, R. (2001).The chicken gut microflora and probiotic supplements. Journal of Poultry Science, 38: 189196.

3. LutfulKabir (2009). The role of probiotics in the poultry industry.International Journal of Molecular Sciences 2009, ISSN 1422-0067 www.mdpi.com/journal/ijms. Engormix.com.

4. Cherkupally, R., Kota, S.R., Amballa, H and Reddy, B.N. (2017). In vitro antifungal potential of plant extracts against Fusariumoxysporum, Rhizoctoniasolani and Macrophominaphaseolina. Annals of Plant Sciences, 6(9): $1676-1680$.

5. WHO- World Health Organization (1992).Quality control methods for medicinal plant materials. Geneva.

6. LinaSernaite (2017). Plant extracts: antimicrobial and antifungal activity and appliance in plant protection (Review). Lithuanian Journal of Agriculture and Forestry, 3(4):58-66.

7. Rates, S.M.K. (2001).Plant as source of drugs.Toxicon Journal, 29: 603-613.

8. Manju, P., Vivek, K., Jaya, P.Y. (2011). In vitro antimicrobial activity of ten medicinal plants against clinical isolates of oral cancer cases. Annals of Clinical Microbiology, 10:21-28.

9. Sathya, B., Jayasurya, K., Sankaranarayanan, S and Bama, P. (2012). Antibacterial activity of different phytochemical extract from the leaves of Tridaxprocumbens: identification and mode of action of terpernoids compounds as antibacterial. International Journal of Pharmacy and Pharmaceutical Sciences, 4(1): 557-564.

10. Khan, R., Islam, B., Akram, M., Shakil, S., Ahmed, A., Ali, S.M., Sissiqui, M., Khan, A.U. (2009). Antimicrobial activity of five herbal extract against multi drug resistance (MDR) strains of bacteria and fungus of clinical origin, Journal of Molecules, 14:586-597.

11. Wang, M.L., Suo, X., Gu, J.H., Zhang, W.W., Fang, Q and Wang, X. (2008). Influence of grape seed proanthocyanidin extract in broiler chickens: effect on coccidiosis and antioxidant status. Journal of Poultry Science, 87:2273-2280.

12. Omokore, E.O and Alagbe, J.O. (2019).Efficacy of dried Phyllantusamarus leaf meal as an herbal feed additive on the growth performance, haematological and serum biochemistry of growing rabbits. International Journal of Academic Research and Development, 4(3):97-104.

13. Alagbe, J.O., Sharma, D.O and Xing, Liu. (2019). Effect of aqueous Piliostigmathonningii extracts on the haematological and serum biochemical indices of broiler chicken. Noble International Journal of Agriculture and Food Technology, 1(2):62-69.

14. Parkash, A., Ng, T.B and Tso, W.W. (2002).Isolation and characterization of lufacyclin a ribosome inactivating peptide with anti-fungal activity from sponge gourd seed. Peptides 23:1019-1024.

15. Olafadehan, O.A., Oluwafemi, R.A and Alagbe, J.O. (2020). Performance, haemato-biochemical parameters of broiler chicks administered Rolfe (Danielliaoliveri) leaf extract as an antibiotic alternative. Advances in Research and Reviews, 2020, 1:4.

16. Partap, S., Kumar, A., Sharma, N.K and Jha, K.K. (2012).Luffacylindrica: An important medicinal plant. Journal of Plant Research, 2:127-134.

17. Ighodaro, I., Agunbiade, S.O., Omale, J.O and Kuti, O.A. (2012). Evaluation of the chemical nutritional, antimicrobial and antioxidant vitamin profiles of Piliostigmathonningii leaves. Research Journal of medicinal plants 6: 537-543.

18. Bravo D, Ionescu C (2008) Meta-analysis of the effect of a mixture of carvacrol, cinnamaldehyde and capsicum oleoresin in broilers. Journal of Poultry Science, 87:75

19. Phyo, H.H.K., Kyaw, S.W., Khin, K.L., Yezin, K.M., Aye, A.M and Khin, H.S. (2017). Effect of dietary garlic and thyme seed supplementation on the production performance, carcass yield and gut microbial population of broiler chickens. Journal of Scientific Agriculture, 1:269-274.

20. Hanan, E.A. (2014). Effect of different levels of Turmeric (Curcuma longa) supplementation on broiler performance, carcass characteristics and bacteria count. Egyptian Journal of Poultry Science, 35(1): 25-39. 
21. Alagbe, J.O., Olanrewaju, A., Adewemimo, A and Tanimomo, B.K. (2019). Carcass, caecal microbial population and immune parameters of broilers given different levels of mixed lemon grass ((Cymbopogoncitratus) and garlic (Allium sativum) extract. Academic Journal of Life Sciences. 5(11): $107-$ 111.

22. Kirsty, K. (2015). Probiotics and enzymes: A good combination. Quarterly magazine of the Animal Feed Manufacturers Association. 24(2): 35-37.

23. Filipe, R. (2014). Adjusting intestinal microflora with synbiotics. Science and Solutions. A magazine of Biomin Pages 14 (4):6-8.

24. Kim, G.B., Seo,Y.M., Kim, C.H and Paik, I. K. (2011). Effect of dietary probiotic supplementation on the performance, intestinal microflora and immune response of broilers. Journal of Poultry Science, 90:75-82.

25. Knap, I., Kehlet, A.B., Bennedsen, M., Mathis, G.F and Hofacre, C.L. (2011). Bacillus subtilis (DSM17299) significantly reduces Salmonella in broilers. Journal of Poultry Science, 90: 1690-1694.

26. Kudoh, K., Shimizu, M., Wada, M., Takita, T., Kanke, Y and Innami, S. (1998). Effect of indigestible saccharides on B lymphocyte response of intestinal mucosa and ceaca fermentation of rats. Journal of Nutritional Science, 44:103-112.

27. Leandro, N.S.M., Oliviera, A.S.C., Gonzales, E., Café , M.B and Andrade, M.A. (2010). Probiotic in the diet of broiler chicks challenged with Salmonella enteritidis. Rev. Bras. Zoology, 39:1509-1516.

28. Li, X.Q., Qiang, L., Liu and Xiu, C.L. (2008).Effects of supplementation of fructooligosaccharide and /or Bacillus subtilis to diets on performance and intestinal microflora in broilers.Achiv. Fur Tierzucht, 51:64-70.

29. Scheurer, W., Spring, P and Maertens, L. (2013). Effect of 3 dietary phytogenic products on production performance and coccidiosis in challenged broiler chickens. Journal of Applied Poultry Research, 22: 591599.

30. Shan, B., Cai, Y.Z., Corke, H. (2005). Antioxidant activity of 26 spice extracts and characterization of the phenolic constituents. Journal of Agriculture, 53: 7749-7759.

31. Srinivasan, K. (2005). Spices as influencers of body metabolism: an overview of three decades of research. Food Research International, 38:77-86.

32. Tassou, C., Koutsoumants, K., Nychas, G. J.E. (2000). Inhibition of Salmonella enteritidisand Staphyllococcusaereus in nutrient broth by mint essential oil. Food Research International, 33:273-280.

33. Viegi, L., Pieroni, A., Guarrera, P.M., Vangelisti, R. (2003). A review of plants used in folk veterinary medicine in Italy as basis for a databank. Journal of Ethnopharmacology, 89: 221-224.

34. Wojdylo, A., Oszmianski, J., Czemerys, R. (2007). Antioxidant activity and phenolic compounds in 32 selected herbs. Food Chem,105: 940 -949.

35. Zinoviadou, K.G., Koutsoumanis, K.P., Bilideris, C.C. (2009). Phytochemical properties of whey protein isolate films containing oregano oil and their antimicrobial actions against spoilage flora of fresh beef meat. Journal of Meat Science, 82: 338-345.

36. Oluwafemi, R.A., IsiakaOlawale and Alagbe, J.O. (2020). Recent trends in the utilization of medicinal plants as growth promoters in poultry nutrition- A review. Research in: Agricultural and Veterinary Sciences. 4(1): 5-11.

37. Davis G.S, Anderson K.E (2002) The effects of feeding the direct-fed microbial, primalac, ongrowth parameters and egg production in single comb white leghorn hens. PoultSci81(6): 755-759.

38. Banjeree P, Pradhan N.R (2006) Live yeasts a good alternative to AGP in broiler chickens. World Poultry 22(8): 32-34.

39. Bakhtiyorovna, A. N., \& Bakhtiyorovna, A. N. (2020). The role of oikonyms in microtoponymis of Bukhara district. Middle European Scientific Bulletin, 4, 41-43.

40. Sadikovna, B. G., \& Farhadovna, K. G. (2020). Monitoring water consumption of the slate manufacturing plant. Middle European Scientific Bulletin, 5, 5-6.

41. Mark, J. (2020). Workplace strategies for work burn-out prevention. Middle European Scientific Bulletin, 5.

42. Jabbarov, I. S., \& Madjidova, T. R. (2020). Influence of environmental factors on binding of hybrid grains of interspecific wheat hybrods. Middle European Scientific Bulletin, 5, 1-4. 
43. Otamurodova, M. (2020). Scientific researches on the journalism esp in foreign universities and in Uzbekistan journalism and mass communication university. Middle European Scientific Bulletin, 3, 7-9.

44. Nargiza, K. (2020). Restoration and conservation works on architectural monuments (on the example of Bukhara). Middle European Scientific Bulletin, 5, 47-50.

45. Ahmedova, A. T. (2020). System of innovative business strategic management of the enterprise. Middle European Scientific Bulletin, 4, 10-13.

46. Ndubuisi, A. G., \& Jacob, O. N. (2020). Managing university degree programmes acceditation in the era of economic recession in Nigeria. Middle European Scientific Bulletin, 5, 56-62.

47. Jacob, O. N., \& Samuel, A. (2020). Educational policy in Nigerian: Challenges of Implementation and Ways Forward. Middle European Scientific Bulletin, 4, 1-9.

48. Babanazarova, S. (2020). About ensuring a fair approach to the effective organization of the professors and teachers work. Middle European Scientific Bulletin, 5, 88-91.

49. DR, D., \& Kh, B. S. (2020). The process of laying the rover on the surface of the cartridge. Middle European Scientific Bulletin, 5, 7-10.

50. Kurtoglu V, Kurtoglu F, Seker E, Coskun B, Balevi T, et al. (2004) Effect of probiotic supplementation on laying hen diets on yield performance and serum and egg yolk cholesterol. Food AdditContam 21(9): 817-823.

51. Line J.E, Bailey J.S, Cox N.A, Stern N.J (1997). Yeast treatment to reduce Salmonella andCampylobacter populations associated with broiler chickens subjected to transport stress. $\quad$ PoultSci 76(9):1227-1231

52. Vicente J, Wolfenden A, Torres-Rodriguez A, Higgins S, Tellez G, et al. (2007) Effect of aLactobacillus Species-Based Probiotic and Dietary Lactose Prebiotic on Turkey PoultPerformance With or Without Salmonella Enteritidis Challenge. J Appl Poultry Res 16(3): 361-364. 